\title{
20 周年記念特集にあたって
}

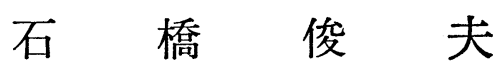

今年はテレビジョン学会が設立されてから 20 年目にあたります. テレビジョン学会 の前身であるテレビジョン同好会が結成されたのは昭和 21 年で, 戦後の荒廃の中で会 合を開いたり, 同好会報を発行していました，その後, 各方面のテレビジョン研究が 次第に活発になり, 昭和 25 年 3 月になってテレビジョン同好会はテレビジョン学会に 発展しました．当時の学会雑誌はガリ版ずりで20頁前後のそまつなものでしたが，そ の後, テレビジョンの発展とともに学会も大きく生長し, 雑誌の方も幾度加体裁を変 えました. 現在のようなテレビジョン学会雑誌テレビジョンという体裁になったのは 昭和29年10月からで, この時から編集だけ学会でやり, その他の仕事は全部日刊工業 新聞社にお願いしていました．乙の状態が約 9 年間続いております，ちょうどテレビ ジョンが急速に普及した時期で, とれにともなって学会の会員数も増加し, 事務の陣 容も整備されて昭和38年11月から学会誌は自己出版に切り替わり, テレビショョン学会

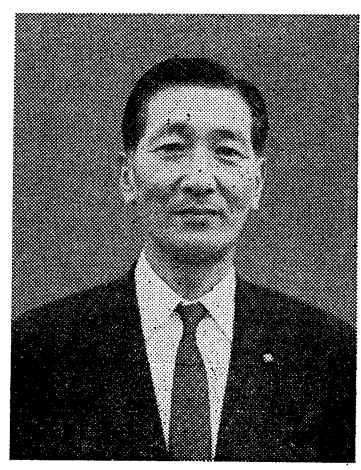
編・発行という本来の形になったのです.

学会誌の変遷のあとは，そのままテレビジョン学会発展の歴史でああり, 学会創立当時 300 名程度の会員数が, 現 在では 6,900 名を越える学会に生長しました，当初の学会の活動は，テレビジョンを放送する系統の技術，受信する 技術およびそれらに使用する電子管の技術が重点になっていましたが, テレビジョン技術の発展, 高度化にともなっ て, 広く電子工学から情報工学, 生体工学等の分野にまたがって活動するようになりました. さらに, 1970 年代の 象徴である情報化社会においてのテレビジョン技術の持つ役割はますます大きく，本学会は今後む急速に生長するす のと期待されます. まことにで同慶の至りです.

本号ではての意義のある20周年を記念して，乙れまで例のないような特集を行なってみました．まず，テレビジョ ンに関連して今後発展する方向と考えられる10項目を選び，それぞれの分野の権威の方々にその動向を執筆していた だきました．乙れらは1970年代の初めに当って，それぞれが今後いかに発展していくかを考えてあらったすのです。 また, 初めての試みとして“21世紀のテレビジョンはどうなるか?”という内容の論説を広く公募していましたので てれを本号で発表いたします. また，乙れも新しい企画ですが，丹羽・高柳両名誉会員および昭和 41 年以後の本学会 会長というこの分野のトップグループと，35才以下というぐっと若々しいグループの 2 つのグループで別々に将来の テレビジョンについて座談会を行ないました．乙れでいろいろな人が描いているニュアンスの違いなどあくみ取れる あのと思います．以上，いろいろな角度からテレビジョンの将来を探ってみました．会員諸氏にとって本号が有益な 特集号になるすのと確信しています.

これまでテレビジョンは，主に放送を目的として発展してきました．そしててれが国民生活の様式に変化を与える までに普及いたしました．アポロ11号の月面からの生中継は1960年代のテレビジョン放送のハイライトといえるむの ではないでしょうか. 100\% 亿近い視聴率だったと聞いております.テレビジョン放送の距離を超越した速報性，広 域伝達性を遗憾なく発揮したあのです，今後ともとのような放送の形は進歩を続けるすのと考えられますが，それ以 上に産業, 教育, 医学などへのテレビジョンの応用が今後急速に発展し, われわれの生活を豊かにするととが期待さ れます.とのようなテレビジョンの動向に対して，会員諸氏が適正な判断を下される一助になれば幸いです.

終りに, 執筆者の方々ならびに本特集を企画された宇都宮前編集長, 遠藤前編集理事に厚くお礼申し上げる次第で す.

（テレビショョン学会編集長・NHK 総合技術研究所主任研究員） 


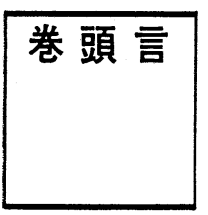

\section{テレビジョン学会創立 20 周年記念特集}

創立 20 周年をむかえて

木

村六郎

昭和 25 年 3 月, 高柳健次郎先生が会長をしておられたテレビジョン同好会が母体と なって，テレビジョン学会が創立されてから，ちょうご 20 年を経過した．との 20 年閒 はまさにテレビ放送の発達期であった。

昭和 22 年に発足したテレビショョン同好会は，テレビジョン技術のようらん期で，赤 ん坊が小学校に入るまでの育ての親が高柳先生であった. 同先生がテレビジョンの父 といわれるゆえんはそこにある. 学会が創立されて, 初代の会長が高柳先生であった ことあ当然であり，そのとろ NHK で始められたテレビジョンの実験放送が，昭和 28 年，正力さんによって創立された NTV とともに本格的放送を開始してから，目ざま しい発展をとげ, 全国 2,200 万世帯以上の普及をみた.

その間に，昭和 32 年頃 VTR の出現，昭和35年 9 月 カラー放送の実施，昭和 38 年12月＼cjkstart衛星中継の実現など，テレビジョン技術の発展は目を見張るばかりである.

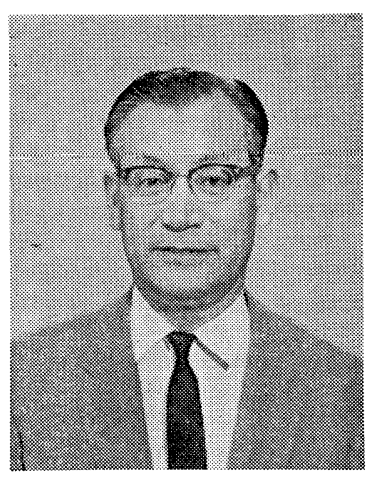
当学会の会員数も, 初めの 300 名程度加, 現在の 6,903 名（昭和 45 年 7 月）と約 23 倍に増加した. いったい, 乙れ からテレビジョン技術はどんなに発展してゆくであろうか.

私はこの 20 年をへて，テレビジョン技術がようやく青年期に入ったすのと思う．なるほど，テレビジョン放送はて の 20 年間で，一人前になったと見てもよかろうが，本号の “21世紀のテレビジョンはどうなるか”という座談会記事 を見ていただけばわかるように，乙れからのテレビジョン技術は単に放送ばかりでなく，いろいろな応用方面に無限 の発達をするものと予測される.

まず, 当面の問題として, テレビ電話, CATV, ビデオパッケージなどがあり，情報化時代にともなうビデオディ スプレイも重要な役割を占めるあのと思う. 現在はカラーテレビ方式として, NTSC が採用されているが, 有線テレ ビ，レーザー伝送が発達すれば，必ずしもNTSC が最良の方式ではなくなり，新しい映像伝達方式が開発されて， 世界のテレビジョン方式が統一されるときがくるであろう.

衛星中継, ないし衛星放送の発達は世界中の意志の交換を容易にし, 低開発国の文化, 産業を向上し, 世界平和の 達成に貢献することも考えられる. おちらくはテレビジョン新方式の開発は, 世界のテレビジョン方式の統一を促進 して，世界中の人をテレビジョンを通じて一堂に会する夢を実現させるのではなかろうか.

一方において, 壁面テレビ, 腕時計テレビ, 立体テレビなどのディスプレイ方式の発達む考えられ, データ通信や 電算機の活用に一段之重要な役割を果たすようになる. ディスプレイむ, ブラウン管方式が, 光素子の発達に伴って 平面的な明るいものとなり, 反射光を利用したディスプレイに変わるととも考えられる.

これを要するに，テレビジョン技術の動向は従来のハードウエア的な進歩とともに，乙れからはソフトウエア的な 発達に, より多くの目を向けなければならない時期にきている. 当学会としてはテレビ電話, CATV, ビデオパッケ ージなど，テレビジョン放送と密接な関係のあるものはもちろん，ビデオディスプレイ，医用電子関係，工業用テレ ビなど，テレビジョン技術応用方面に目を向けて，てれら応用分野の発展に資することを考えたい．乙のために関係 学会との連繋を密にして，学術の健全な発展をいままで以上に念頭において進まなければならないと思っている.

ての意義ある年に, 私が会長に推されたことは, その重大な責任を痛感するととすに, 身にあまる名誉であり, 先 輩諸賢のあとを慕い，役員諸氏ので支援を得て，会員ととむに，てれからの洋々たる前途を歩みたいと思う.

（テレビション学会会長・読売テレビ放送株式会社常務取締役） 


\title{
To My Fellow Engineers
}

\author{
V. K. Zworykin
}

My fellow engineers,

I am greatly honored by your request to contribute some opening words to this special issue of your journal which commemorates the twentieth anniversary of the Institute, and I congratulate you all on the astonishing achievements you have made in this period of time.

My first visit to your country occurred in the early decades of this century. From this vantage point, I feel fortunate to have witnessed from its very beginning not only the phenomenal growth of TV in your country, but indeed the incredible electronic renaissance which happened in recent years.

I remember with pleasure my conversations with the eminent Professor Takayanagi when he visited the RCA Camden Laboratories in 1934 and

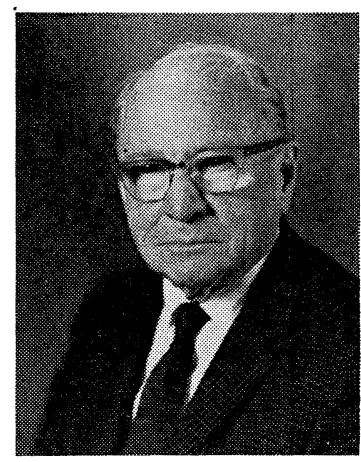
our correspondence that followed. And of course my wife and I can never forget our trip in 1955, at the invitation of Sangyo Keizai, to lecture on TV. We had such wonderful associations with men such as Senator Maeda, Mr. Katsuda, Dr. Hayashi, Dr. Niwa, Dr. Ishikawa, Minister Matsuda, Minister Ishibashi, Dr. Yukawa and so many, many others.

How extraordinary and universal is the engineering language we speak, and how extraordinary the manner in which developments in our very special language occur. The night before I left your country in 1955, I met in my room, at the lovely Imperial Hotel, with a group of engineers who were interested in applying engineering techniques to medical problems-one of the major preoccupations of my life. Today, these men and their President, Dr. Sakamoto, are your country's leaders in this vastly expanding and world-wide field, a field that holds great promise for the future of man in his fight against what is his most personal and most deadly enemy.

I have often pondered in my long life about how these developments occur and the part we engineers and scientists play in the process. I remember the dreams of Professor Boris Rosing, the man who introduced me to the discipline that eventually became television. He wrote in 1910 that "the electric eye will permit man not only to commune with other human beings, but also with nature itself." I also remember, sometimes sadly, what my own hopes for television were.

We now know that such prospects become reality only when large interests become involved in their development-in the case of television, commercial and communications interests. We might pause sometime and ask ourselves if what we created has lived up to our expectations. In my own experience, one of the dreams I remember most for television from my youth was to be able to see what was on the moon, indeed what was on the side forever hidden from the earth. I have lived to see it and most of you will see much farther into the universe.

The fruition of our work has brought great material benefit to humanity. Millions are now employed in industries that did not exist a generation ago. Through our efforts, the world is a smaller, closer place. 


\section{創立 20 周年記念特集}

Humanity, in all parts of our earth, has finally been revealed for what it is and always was-a common family with common interests-peace, safety and prosperity for our children and our life. We, my colleagues, have much to be proud of.

But never, in this dazzling and successful panorama, let us forget the moral obligation we have to humanity in whatever we do. Much remains to be done and much remains to be changed. We who have created the techniques that can be so beneficial to mankind have an obligation to do whatever we can to insure that these techniques are used as we intended-for the betterment of our fellow man. We are a small family, after all. And in a filial manner then, let me congratulate you on your anniversary, and hope your next two decades will be as extraordinary as your first two. I have always regarded it as a special honor to have had a share in your endeavors as a member of the Institute of Electronic Communication Engineers and the Institute of Television Engineers of Japan.

\section{学会員の皆さんへ}

テレビジョン学会創立 20 周年を記念する本特集号に巻頭言を寄稿するようにとのご依頼を受け 誠に光栄に感ずるととむに，乙の 20 年間に㫮さんが得られました驚くべき成果に対してお祝い申 し上げたいと思います.

私が初めて日本を訪れましたのは今世紀の初めの頃でありました。てのとき以来，貴国に抢ける 画期的なテレビジョンの発達と, 近年の正に信じがたいほどの電子工学の復興を, その初めからま のあたりにするてとができたととを幸いに思っております。

私は，1934 年に高名な高柳教授が， RCA のキャムデン研究所を訪問されました折の会話之， その後の私達の文通を楽しく思い出します， あち万ん，1955 年に産業経済新聞社のお招きでテレ ビジョンについて講演するため日本に参りました旅を, 私の妻ともども決して忘れるととはできま せん. 私どもは, 前田参院議員, 勝田氏, 林博士, 丹羽博士, 石川博士, 松田郵政大臣, 石橋大蔵 大臣，湯川博士その他の誠に多くの方々と実にすばらしいで交際を得たのであります．

私達の話す技術のととばというあのは, 何と非凡で万能なむのであり, またその特別なととばが 発達する様子は何とすばらしいものでありましょう，1955 年に私が貴国を立つ前夜に，私は美し い帝国ホテルの私の部屋で私の生涯の重要な関心事のひとつである医療問題に技術手法を応用する ことに興味をあつ技術者の方達とお目にかかりました．今日，乙れらの方達とその主莘者である阪 本博士は，乙の大きく拡張しつつある世界的分野の貴国における指導者であります．乙の分野は， 人類にとって最む身近な，そして最む致命的な宿敵に対する闘いの将来に大きな希望をいだかせる あのであります.

私は，自分の長い生涯の間に，乙のような発展がいか却起とり，その過程において，われわれ技 術者や科学者がいかに貢献するかについてたびたび思いをめぐらせました.

私は, テレビションの基礎となった原理に私を導いてくれた Boris Rosing 教授の夢を思い出し ます. 氏は，1910 年に“電気の眼は，人間が他の人間とのみでなく，自然そのあのとも交わり合 うととを可能にする”と書きました．私はまた，ときおり私自身のかつてのテレビジョンに対する 願望をうら悲しく思い出します.

われわれは今日，そのような期待は大きな利害が関係してきたときにのみ実現されるということ を知っており，テレビジョンの場合には，商業上および通信上の利益というととが含まれていたの だと思います．われわれはときおり立止まって，われわれが創造したものは本当にわれわれの期待 ど抢りのあのとなっているかを自らに問うて見たほうがよいのではないでしょうか. 私自身の経験 では, 若い頃からのテレビジョンに対する夢のひとつとして最む心残っているのは, 月面上の 物, それも地球から永久に隠された側面にあるあのを見るととができるというととでありました. そして私はその月の裏側を見るまで生きてきました，皆さんの多くは宇宙のさらに奥まで見ること でしょう. 
われわれの勤労の結果によって人類には大きな物質的利益があたらされました．現在，何百万人 あの人達が一世代前には存在しなかった産業に従事しているのです。われわれの努力によって世界 はより小さい,より緊密な土地となりました。

人類は，わ执われの子供達とわれわれの生活の平和，安全そして繁栄という共通の利害をむった 共通の家族であり，常にそうであったととを自ら示したのです．皆さん，われわれは誇るべき多く のあのをあっているのです.

しかしわれわれは，乙の目がくらむような成功のパノラマの中にいて何をなすにす人類に対する 倫理的な責任を忘れてはなりません．まだなすべきてとは多く，改変すべきてとも多く残っていま す.人類にとって非常に有益であるべき技術を創造したわれわれは，その技術が，意図したとおり， われわれ人類の利益のために使われるととをできうる限り保証する責務があります．結局のところ われわれは小さな家族であります．私は家族の一員として，貴学会の記念日をお祝いし，皆さんの 今後の 20 年間がこれまでの 20 年間と同様にすばらしいものであることを期待したいと思います. 私は自分が日本の電子通信学会およびテレビジョン学会の一員として，皆さんと努力をとあにして きたととを特別に光栄に思っております.

(テレビショョ学会名誉会員・RCA 名誉副社長)

\section{Vladimir Kosma Zworykin}

1889 年, ロシアの Mourom に生まれ, ペテログラ ード工科大学にて電気工学を学び，その間 Brois Rosing 教授の指導を受けて, テレビジョンおよび電子工 学に対する興味をむつに至った. 1912 年,パリのフ ランス大学に入学, 著名な Paul Langevin 教授の下 でX線の研究に従事した．第一次世界大戦後，米国に 移住し，1924 年，米国市民権を得，1926 年にはピッ ッバーグ大学から Ph. D. の称号を受けた.

米国移住後ただちにウエスチングハウス社の研究ス
タッフに加わり, 光電子放出の研究からアイコノスコ 一プを発明し，また，その後，キネスコープを開発し て今日の全電子式テレビジョン実用化の先駆者となっ た.

1954 年以降は, RCA 名誉副社長兼研究所顧問のほ か, ニューヨークのロックフェラー財団の医用エレク トロニクスセンターの所長を勤めた。

現在は, IEEE 医用エレクトロニクス専門部会の会 長, その他の要職にあって, 特にエレクトロニクス技 術の医学および生物科学分野への応用に関心をもって いる. 


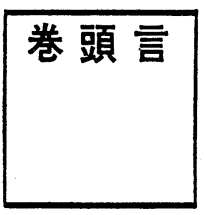

\section{テレビジョン学会創立 20 周年記念特集}

\section{これからのテレビジョン}

\section{丹羽 保 次 郎}

ラジオとテレビとをくらべると，その発達の過程が逆である. 電波が通信に利用さ れるようになって最初に実用されたのは，移動する船舶と陸上との通信であった．今 世紀の初め頃である.かく移動するものとの通信は電波を利用するととによって初め て可能になった。 その後, 通信の距離がのびて, 大洋を越えて大陸間の通信に利用さ れ，海底電信と競争するようになった．第一次大戦の前である.

その頃，今世紀の初め頃から芽生えた真空管が完成され，火花式や電弧式で発足し た無線通信が真空管式に置き換えられ，さらに無線電話にまで発展し事業的にも拡大 した.

第一次世界大戦が終ったとき，乙れらの伸展した無線技術と無線産業とは，何か新 しい面を見出さなければならず，そてに生まれたのがラジオの放送である．戦の終っ て間もない1920年に，ピッツバーグのウエスチングハウスの研究所から毎夜放ってい

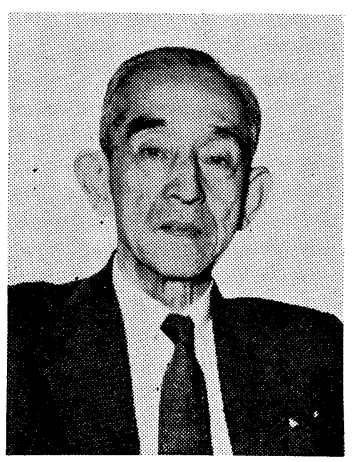
た音楽の電波が受聴者の興味をよび，世界最初の KDKA 局が生まれ，たちまちにして米国の全都市にラジオ放送が 局広がり, 日本でも 5 年の後に放送が開始されるに至った。

ラジオ放送は電波の広播性という特長をうまく利用したもので, 電波の応用としては最も適切なものであって, 2 定点間の通信に電波を利用するととはむしろ特殊の場合であるが, 発達の過程をみると, ラジオの場合は明らかに特 別の場合から発足して，放送がこれに続いたのである.

しかるにテレビジョンについては，乙の関係が逆である．乙れにはいろいろの原因があろう．第一はテレビジョン の技術は非常に高い水準を必要とする．したがってテレビションの構想はずい分古くからあっても，鑑賞しうるよう な，または実用しうる程度の精巧な像を得るまでにはずい分長い年月の生みの悩みをあった。そうしててれが完成さ れたときは，ラジオ放送はすでに瓓熟の時代になっていた．第二次世界大戦前，テレビジョンはすでに放送可能であ った.

てれが戦時中発達した超短波などの技術と産業とに促進されて，乙れらは戦後の転換においてテレビジョンに移行 した．そうしてまたたく間に広がった。ちょうど第一次大戦後におけるラジオ放送と同じである.

かくテレビジョンでは放送からまず実用化された，そうしてテレビジョンをインテリゼンスの伝達の方法とすると とは後回わしになった.ラジオの場合と反対である.

日本においてテレビジョン放送の開始が論議されたとき尚早論が多かったのも, 当時まだ産業界が立ちなおってい なかったこともあるが，テレビジョンはその発達の経路からして何となく娛楽的の印象を与えていたととが大きな原 因でったであろう.

しかし，テレビジョン放送が日本に扔いて始まってから，むはや 20 年になる. 放送開始当初の 2,3 年はその伸びが カナダ、イタリアなどの実数に比し低く, 関係者の憂慮を招いたが, ひとたびての危機を脱するや急速に伸長して, いまやその数 2,000 万を越し, 米国に次ぐ世界第 2 のテレビ普及国になってしまった. カラーテレビあ同様で, 低迷 せる時期を脱してからは急速に広がり，テレビ受像機の過半がカラーになるのもそう遠くはないであろう.

かく日本に拉けるテレビ放送が発達したについては，わが国の驚異的な経済発展と国民所得の増加，テレビ局の普 及と番組の多様化，民放の存在，番組向上に対する熱意之競争心理，テレビ観賞向きの国民性など，いろいろの原因 が考えられる．乙れらの要因は今後も続くに違いない，国内的には各家庭 2 台，3台化の促進，全テレビ受像機のカ 
ラー化などああろうし，また外国輸出にしてあ，従来より困難を伴うとしてあ，全然その将来を期待できないわけで はない，私はテレビジョン放送は技術的にもまた工業的にも今後すますます発展してゆくことを信ずるが，私がこて に強調したいととは，テレビジョンの今後が情報の伝達方式としてのテレビジョン，教育方法としてのテレビジョ ン，通信方式としてのテレビジョン，自動制御や電子計算機の入出力など産業機器としてのテレビジョンなど，放送 以外のテレビジョンに大きな将来が残されているのではなかろうかというととである.

テレビジョンの特長は，それが視覚に訴えることである．ある学者は人間の五感の利用価値を，視覚 $60 \%$, 聴覚 20 $\%$, 触覚 $15 \%$, 味覚 $3 \%$, 嗅覚 $2 \%$ といっているほどで, 視覚によるのがあっとも大である. この数字は少し古いの で，テレビの発達した今日では視覚の占める割合があっと大きくなっているのではないかと思う。したがって，放送 以外の目的にテレビが活用されることは当然で，本特集号においてもその応用がいろいろと論ぜられている. しかも これらの応用は，最近のテレビジョン技術の驚くべき進歩発達に裏づけられている. たとえばVTR の技術がこの頃 非常に進歩した．とれによりテレビ像を簡単に記録保存し，持ち運ぶことができ，また欲する時間に，欲する場所で 再生することができるようになった．受ける時間をきめられていたテレビ放送の欠点を除くことができ，教育の目的 などには大きな進歩といえる.

私は，その発達の過程に执いてラジオと逆の路をたどったテレビジョンが，いよいよ放送以外の方面に活用される 時期がきたように思う．私は技術的にもまた産業的にあテレビジョンがての新しい面にあ大きく伸展するととを希望 するものである.

(テレヒシション学会名誉会員・東京電機大学学長) 


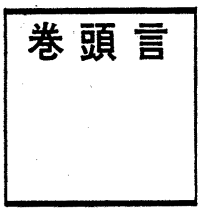

\section{テレビジョン学会創立 20 周年記念特集}

\section{創立 20篮周年を祝して}

高 柳 健 次 郎

今回テレビ学会が創立20周年を迎えられ，ここに海外よりも Dr. V.K.Zworykin の 御来臨を得て, 盛大に記念式典を催されるととは, まことに喜ばしく心より御慶びを 申上げたいと存じます。

終戦間むない頃でした. 私達少数の熱心なテレビジョン研究者達は, 日本のテレビ ジョン技術の発達之実用化を祈念して, テレビジョン同好会を結成しました.

そして, 終戦直後の経済および思想の混乱時代にかかわらず, 毎月例会を開き，熱 心に講演，討論研究会を開いて研究に精進いたしました．私達は当時を回想して，ま ととに感慨深いあのがあります.

会員諸兄の熱意が報いられて, ようやく日本のテレビジョン研究は, 有線による送

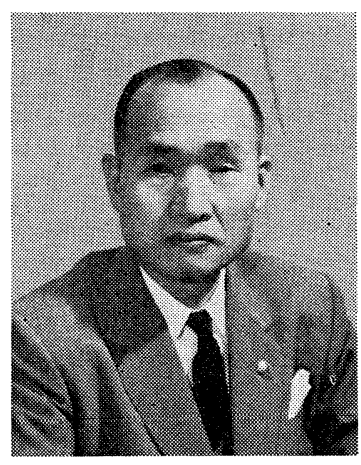
受像研究から，VHF 電波を使用してのテレビジョン送受にまで進展し，昭和 25 年頃からは，次第に実用化の機運が 盛り上がって参りました.

そしてテレビジョン同好会は会員数も数百名に達し, 急速に増加する状態となりましたので, 将来の正常発展に備 えるために，昭和25年 3 月, テレビジョン同好会をテレビジョン学会と改名し，それに伴い組織む整備改正いたしま した. 私は同好会の委員長から，押されて初代のテレビジョン学会会長に選任された次第であります.

その後, 日本のテレビジョン研究開発は, 官民の協力支持によって, 急速かつ順調に進展し, 昭和 28 年白黒テレ ビ，昭和35年カラーテレビの放送実用化が行なわれ，テレビ受像機の普及において米国につぐ発達をとげ，また機器 の生産販売に扔いて産業の重要な分野を築き上げましたてとは，まことに喜ばしい限りであります.

私は，日本がかくあみごとなテレビ事業の発展を遂げたのは，テレビジョン学会会員諸兄ので努力，で協力による あので, 私はそので努力とで業績に対して深く感謝いたしたく存じます.

さて, テレビジョンの発達進歩は今日に止まるあのでなく, 今後10年〜20年にわたって, テレビジョン機器および 方式の進歩, テレビジョン信号伝達方式の改良および普及と, 電子計算機によって代表される情報方式の発達との複 合によって，印刷-ラジオーテレビにつづく第四次の新時代が開発されるでありましょう.

私は, テレビジョン学会会員の諸兄がこれらの新時代において最も重大なる役割を果たし, 世界の文化の進歩, 産 業の発達に大いに貢献されることを期待し, そしてテレビジョン学会がそれによってますます隆盛になり, 創立30周 年〜創立 40 周年を盛大に迎えられるととを祈念して，とてに御祝いの言葉といたします。

（テレヒシション学会名誉会員・日本ヒクター株式会社専務取締役） 